\title{
凍結䡎燥豚皮と人工皮瓦を併用した口腔外科手術釗療法
}

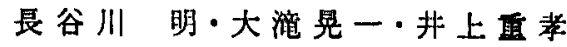

土田有宏・本田洋之

\section{Use of lyophilized porcine skin and artificial skin for raw areas in oral surgery}

\author{
Akira Hasegawa - Koichi Otaki - Shigetaka Inoue \\ Tomohiro Tsuchida - Hiroyuki Honda
}

\begin{abstract}
啨
흠

口腔外科領域の手術に伴5 raw surface に対しては,

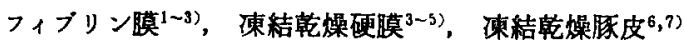
などの材料が応用され手術創を保菨する療法が行われる ようになった。かれわれす最近では，凍結斡燥原皮を raw surface に適用し良好な結果を得ている。

一般に，凍結乾燥豚皮を使用する場合，その効果を十 分発揮させるためには，それを raw surface に密着させ ておく必要がある。この手段として，一般にはガーゼ压 接法が行われ，また plate による固定法などす報告され ている. われわれの行っている凍結㛺燥原皮の圧接固定

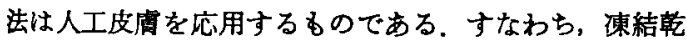
蜗豚皮を raw surface に適用したならこの上に酢酸ビ二 一ル樹脂から製造された人工皮府を压接し，これを創周 囲組織に释合するもので，ガーぜ交換， plate 作製固定な どのわずらわしさるない，より簡便で有効な手術創療法 と思われるので報告する。
\end{abstract}

\section{使用材料および使用法}

凍結乾燥豚皮としては，大鵬薬品より発壳されている フロフスクを使用した（写真1）。本品は健康な豚の背 部および側背部の涷結乾嬠した皮を $\gamma$ 線で照射减菌して 得られたあのであり，白色〜淡黄色，また灰白色〜暗欧 色で，全面が同一色の場合もあり，斑状の場合すある.

厚さは 0.1〜0.5 mm の乾燥皮で毛穴を有し，表皮側に は銀面模様を認め，毛を有しない，大きさはSサイズ

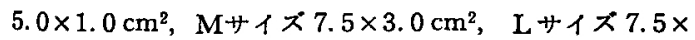

日本歯科大学新渴齿学部口腔外科学教室第 1 諈座 （主任：西村恒一教授）

The First Department of Oral Surgery, Nippon Dental University, Niigata (Chief: Prof. Koichi Nishimura)

受付日：昭和55年11月25日

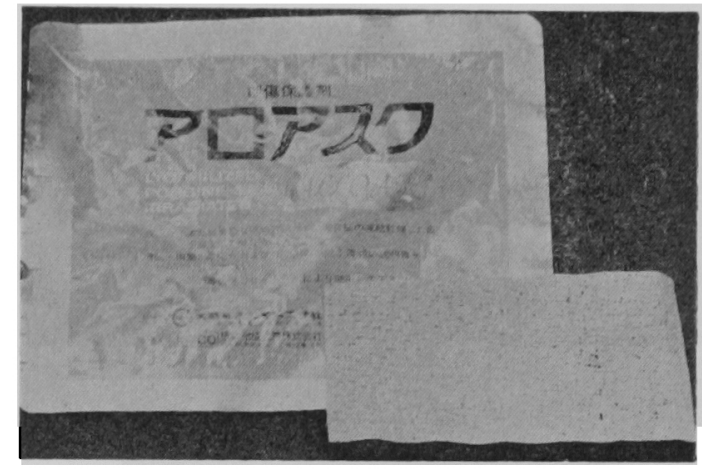

军真 1 凍結乾蜾厔皮

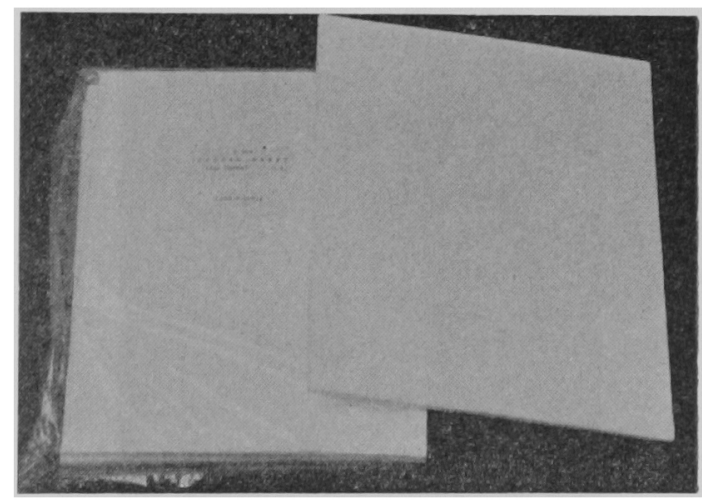

写真 2 人工皮质

$6.0 \mathrm{~cm}^{2}, \mathrm{LL}$ サイズ $20 \times 30 \mathrm{~cm}^{2}$ がある. 使用に当って は，隇菌生理食塩液に15 30分間浸漬して完全に柔軟化 させ，本品の真皮側を㓣面に貼布し密着させた。

人工皮庙は，ヶイ七イ医科工業より発売されている P.V.F-sponge で（写真 2 ), 本品は酢酸ビニール樹脂か ら製造されたポリビニールアルコールをホルマール化し たものであり樹板状連続気孔という特茱な棈造をるって いる. 気孔の平均孔径は $300 \mu$, 気孔字 $92 \%$ で厚さは, 


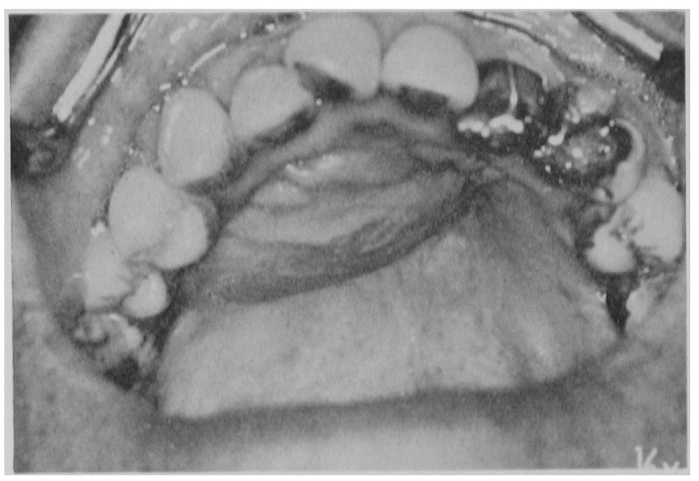

军更 3 術的口腔内所見

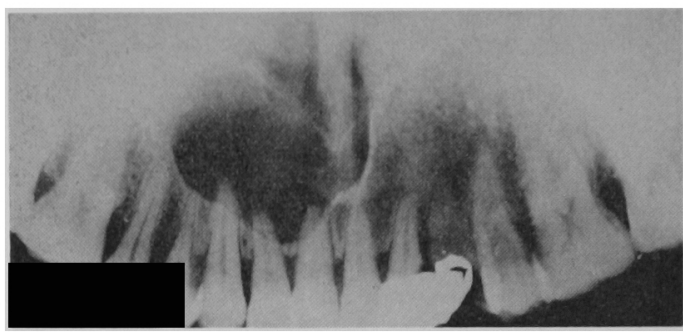

写真 4 X線写真所見

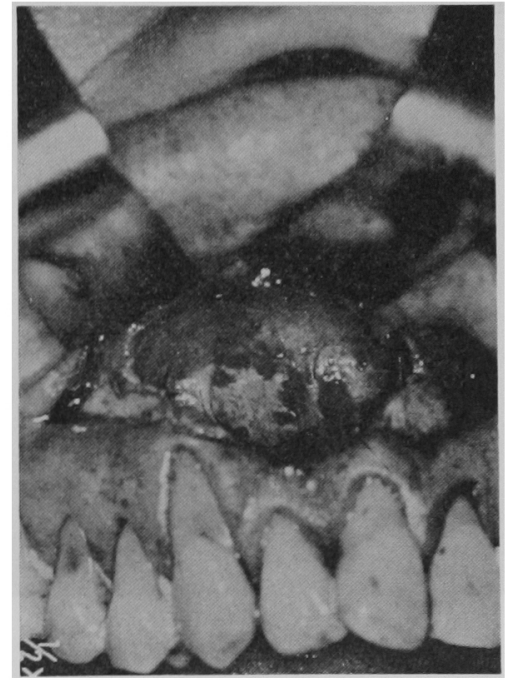

写直 5 手很持所見

6〜 7 mm である，使用前炕 煮沸消毒し，固定は創面 周囲の健康粘膜に綟系で縫合することによって行った。 なお市販されているまま厚さで口腔内に適用すると異 物感が強く，焉た食物摂取などの刺激により脱落する機 会む多くなるので，あらかじめ厚さを半分にし準備して 出きこれを消毒して使用した。

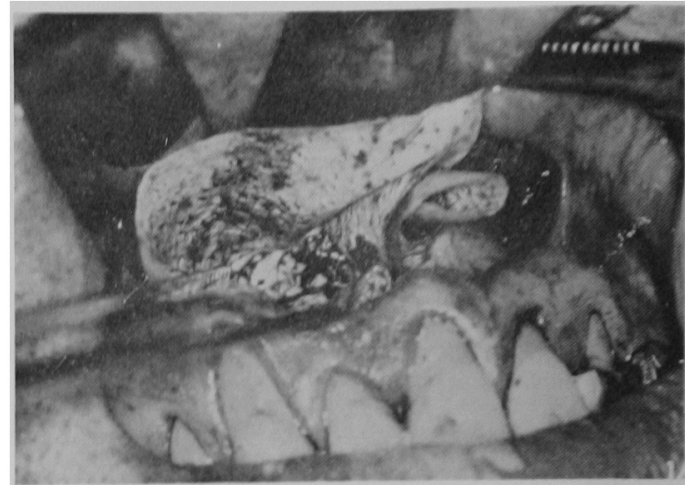

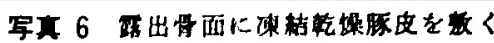

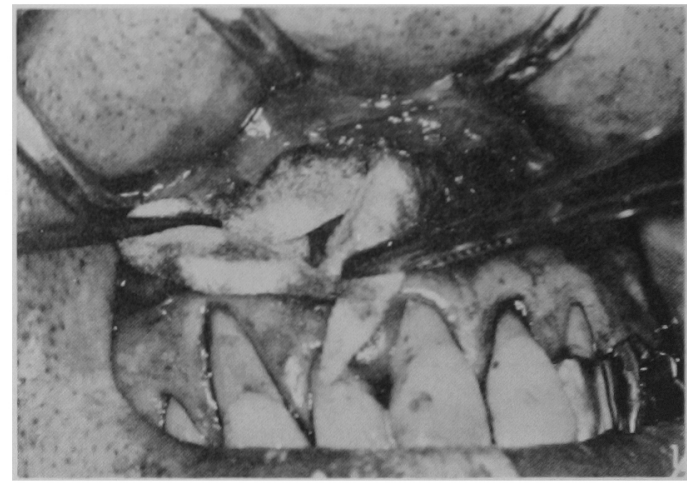

写重 7 人工皮清を括人

症例

\section{1. 額骨显出剖への応用例}

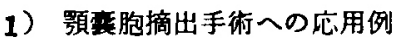

48歳の男性で，口蓋部の膨隆を主訴に来院した症例で ある.

6〜111 口蓋部には半球状の膨隆を認め，被覆粘膜は やや暗色を呈して，触診により波動を触知した（写真 3). 唇煩側部では， $3 \sim 1 \mid$ 歯肉唇移行部にびまん性の 膨隆を認め。この部に羊皮紙様感を触知した，患側歯の

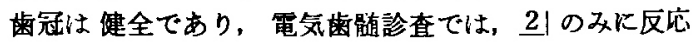
がなかった。

$\mathrm{X}$ 線写真所見では，4〜11 歯根尖部に 卵闩形の X線 透過像を認めた（写直 4 )。

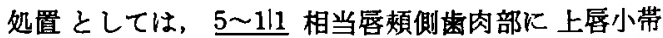
を避けて菡頸部に沿った切開を加え粘膜骨膜を剩離して

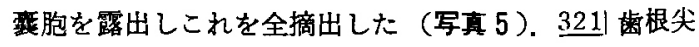
は軎胞内に突出していたため，同時に歯根尖切除手術を

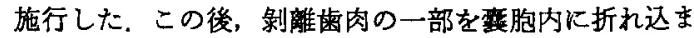
せ露出骨面に凍結乾燥豚皮を敷き（写真 6)，次いで， 震胞腔内に充満するよらなかたちで人工皮凬を挿入し， 


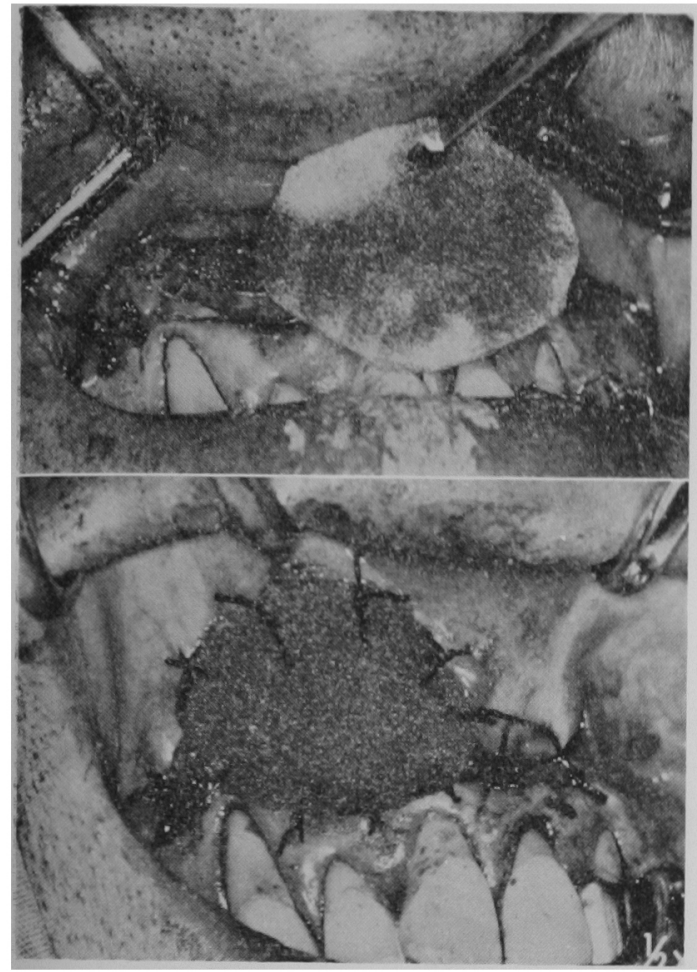

写真 8 創部全体を別の人工皮咸で被覆し，これを 周囲租機に合固定

凍結乾燥豚皮と露出骨面との密着をはかった（写重 7). 最後に創部全体を別の人工皮底で被覆し，これを周围組

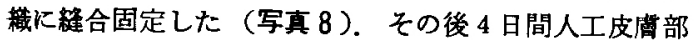
は，抗生物質の溶液で洗涤し，I週後にこれを除去し た. 人工皮唐除去時の所見では，凍結乾燥㕄皮は原型を 保っていたが局所に痹着していた（写真 9)。人工皮茠 䟻去後 3 日目の所見では，凍結乾燥豚皮は融解して灰白 色苔状物様となり周囲組織に 移行を示した（写直10）。 自覚的には特別の訴之がなかった。人工皮底除去後12日 目の所見では，灰白色苔状物はその範围をせばめ創部は 新生粘膜で被覆され周囲健常粘膜との移行も滑らかであ った (写真11).

2）口蓋弁を使用した口腔上顎洞㾇閉鎖手術への応用例 36 歳の女性で，某開業医の所で 6 |の拔歯手術を受け たか，その際口蓋根が上䋶洞内に迷入し，これを主訴に 来院した症例である。

開業医での拔歯後 5 日目に来院したため抜菌窩はすで 飞肉芽によって閉鎖されており，周囲組織にも炎症症状 はなかった。

X線写真所見では 6 | 口蓋根が穿孔部近くの上顎洞内 に存在しているのを確認した。

処置としては，抜歯窩内の肉芽を掻爬し，抜歯窩周囲 より洞底部の骨を除去し，抜歯窩を拡大して迷入根を摘

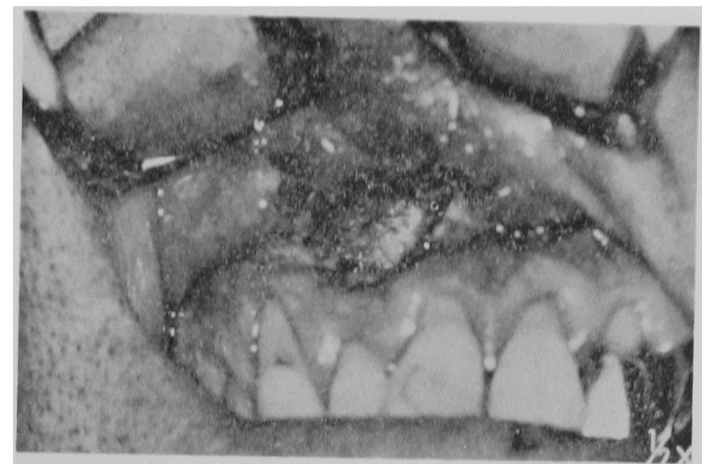

军直 9 人工皮除去拈の所見

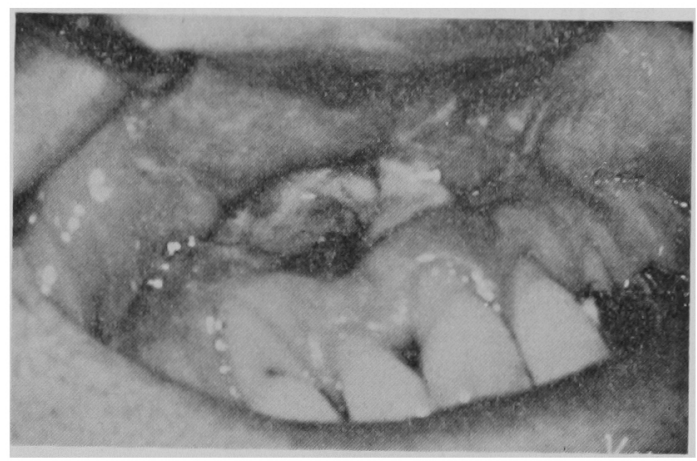

写真 10 人工皮清去後 3 日目の所見

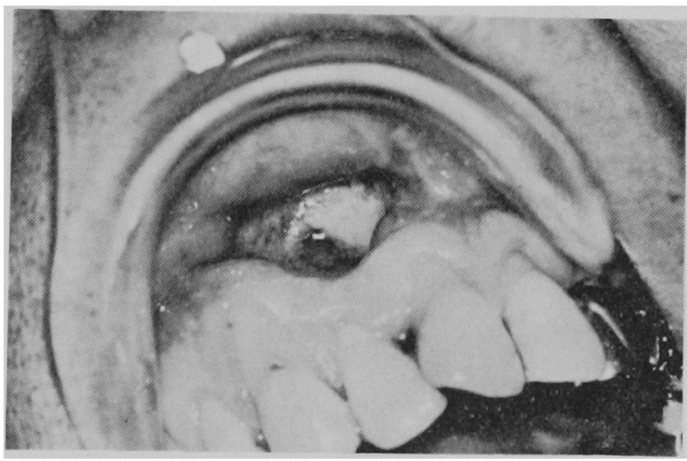

写直 11 人工皮府除去後12日目の所見

出した，次いで，口蓋粘膜骨膜弁を使用し，口腔上顠洞 瘦の閉鎖手術を施行した（写真12）、口蓋并移動後の骨 露出部には凍結䩐燥豚皮を敷き，この上に人工皮绳を当 てがい周囲組織に䋖合固定した（写真13）。その後 3 日 問人工皮扂部は，抗生物質の溶液で洗涤し， 1 週後にこ れを除去した。人工皮膚除去時の所見では凍結乾燥豚皮 は局所に㾍着しやや融解した所見を示していた。周囲に は肉芽の増殖を認めた（写真14）。工皮唐除去後 1 日 目の所見では，凍結乾燥豚皮部は皮白色苔状物様となり 周囲組織に移行を示した (写真15)。自覚的には酸味, 


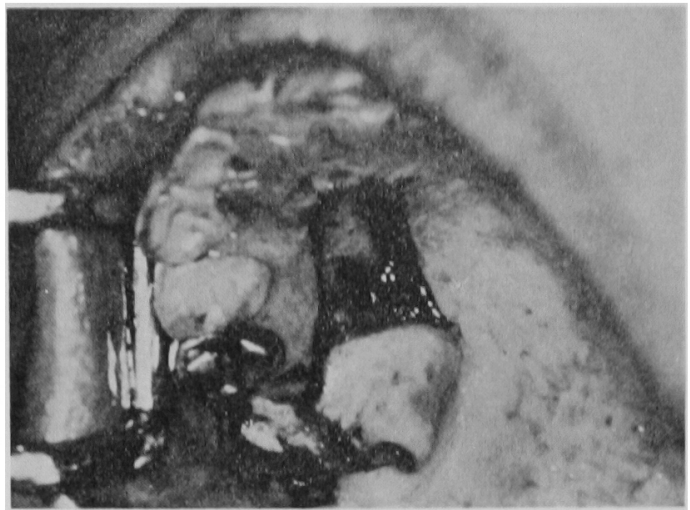

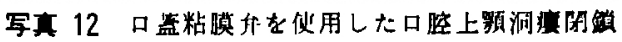
手继

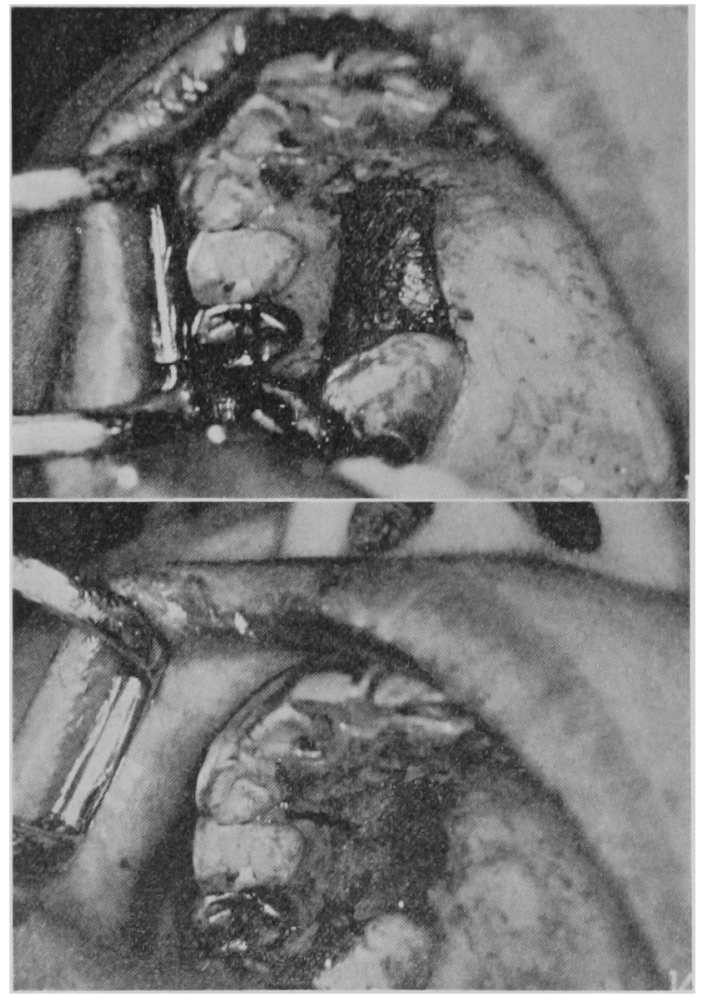

写直 13 骨簬出部に凍結乾燥豚皮を数き，この上 に人工皮腐を当てがい周国組織に䋖合固 定

塩味にやや鋭敏である以外特別な訴之はなかった。人工 皮虔除去後 3 日目の所見では灰白色苔状物は範囲をせば め周囲には上皮の新生を認めた（写真16）。酸味，塩味 に対してる鋭敏に感じることはなくなった，人工皮虚除 去後 1 週目の所見では，灰白色苔状物は痕跡程度となり，

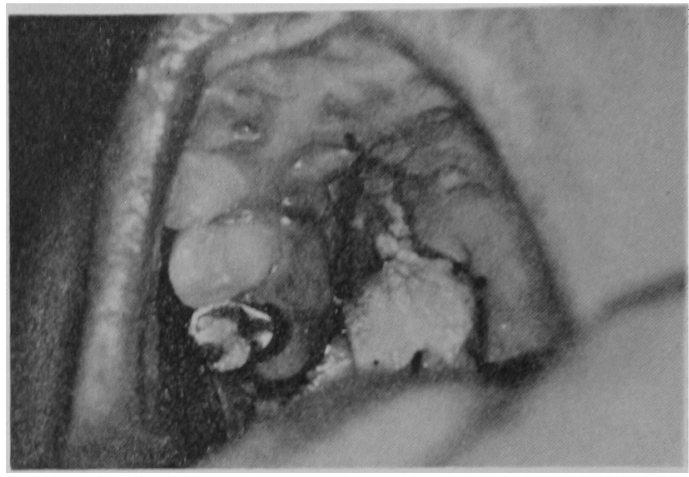

军真 14 人工皮流除去时の质見

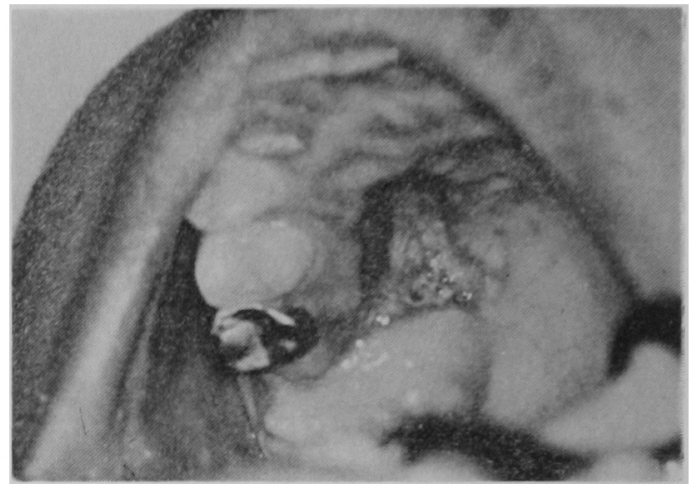

写真 15 人工皮成除去挠 1 日目の所見

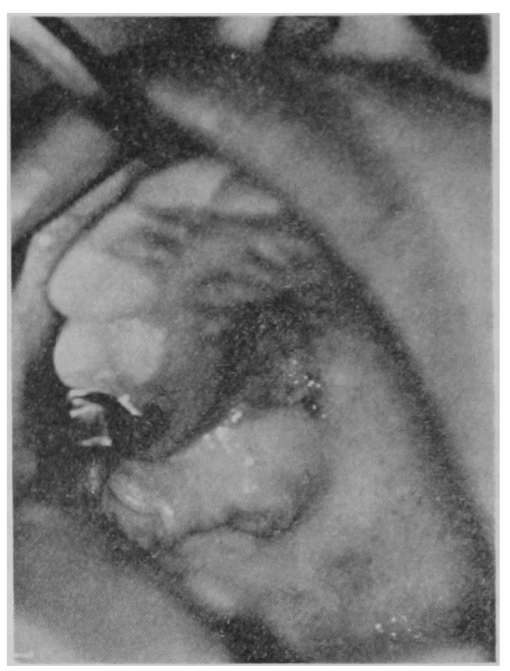

写卉 16 人工皮闻除去後 3 日目の所 見

創部は新生粘膜で被覆され周毌健常粘膜との移行も滑ら かであった（写真17）。 


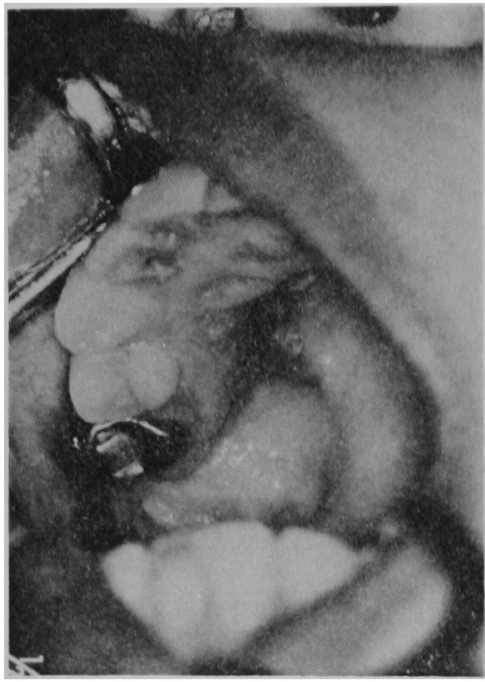

写充 17 人工皮席除志後 1 週目の 所見

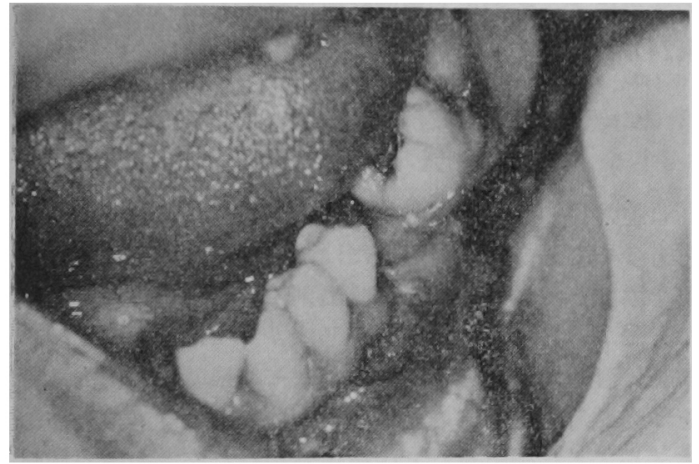

写真 18 術前煩小带所見

\section{2. 軟組織管出創への応用例}

1）賽小帯切除手術への応用例

29 歳の女性で $\sqrt{6}$ 部の補棳処直を受けるために某開業 医のもとを訪れたところ，この部における煩小帯の異常 を指摘され，この切除を目的として来院した症例であ る.

煩小帯は $\sqrt{5}$ 遠心歯慒頂より 煩粘膜方向に巾広く付着 していた（写真18）.

処置としては骨膜を露出させたままにして二次的に上 皮化させる方法により行うこととした，すなわら煩小帯 付着部よりやや広めの切開を加え，次いで煩小帯を含む 粘膜を骨膜から鈍的に的離し歯肉頓移行部に基部をるつ 粘膜弁を作成した。十分な深さまで粘膜の剥離が進んだ なら，粘膜弁の先端を新しく形成された歯肉煩移行部に 折れこませ，その状態のままで粘膜升先端を頓部軟組織 飞䋖合した，露出した骨膜面には倲結乾燥豚皮を敷き

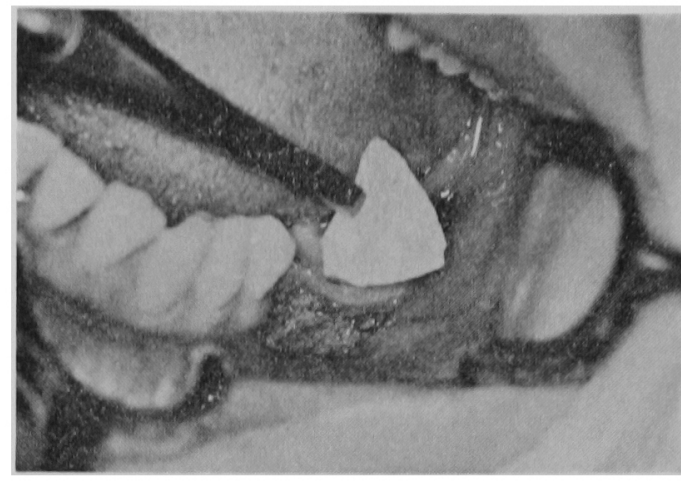

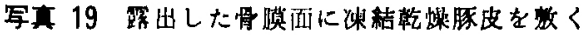

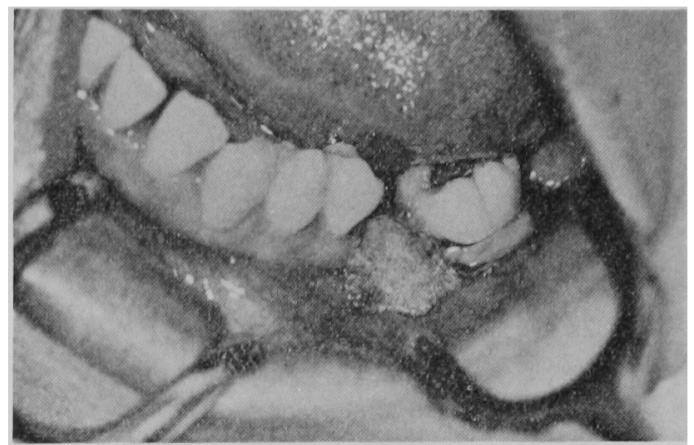

写真 20 人工皮消を当てがい周囲租織保合固定

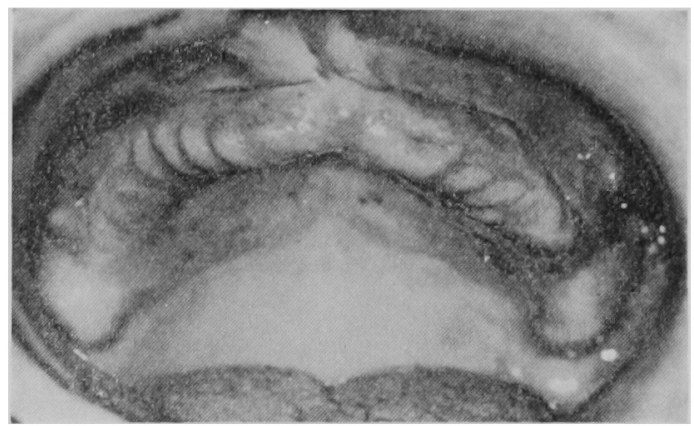

写重 21 コンニャク状買堤を示す術前所見

（写真19），この上に人工皮店を当てがい周囲組織に繾合 固定した（写真20）。人工皮虐はその後 4 日目に除去し たが凍結乾燥豚皮は局所に瘾着しやや融解した所見を示 していた.

2) Flabby tissue 切除手術への応用例

53歳の女性で上枵義歯不適合のため某歯科医院を訪れ たところ，歯肉部の異常を指摘され当科に来院した症例 である.

上頻前歯より小曰歯にかけての筫堤は異常に厚く浮動 性で、いかゆるコンニャク状顎堤の 所見を示していた 

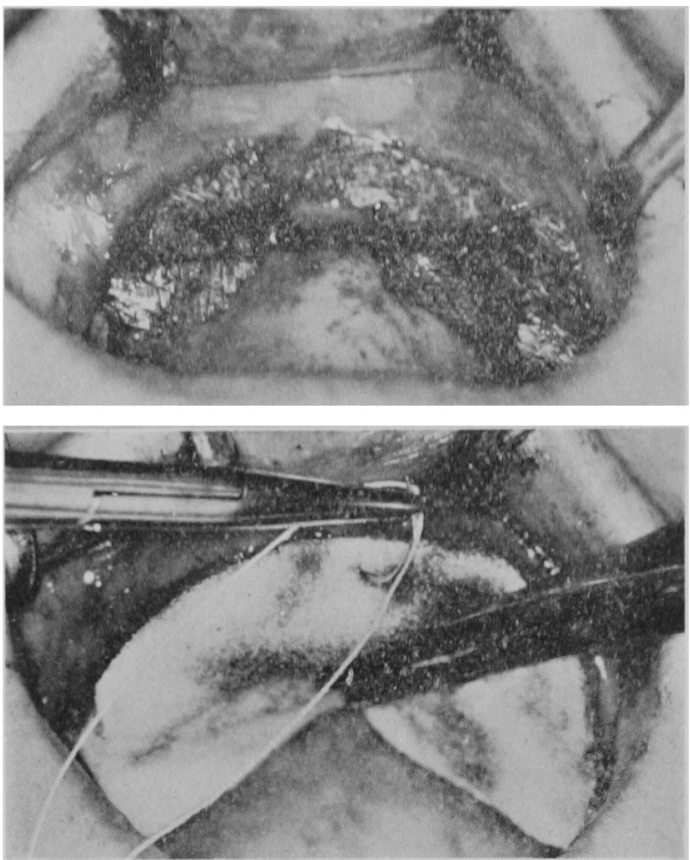

写真 22 露出創画に凍秸乾煤豚皮を㜞き，人工皮

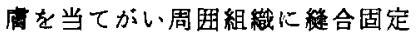

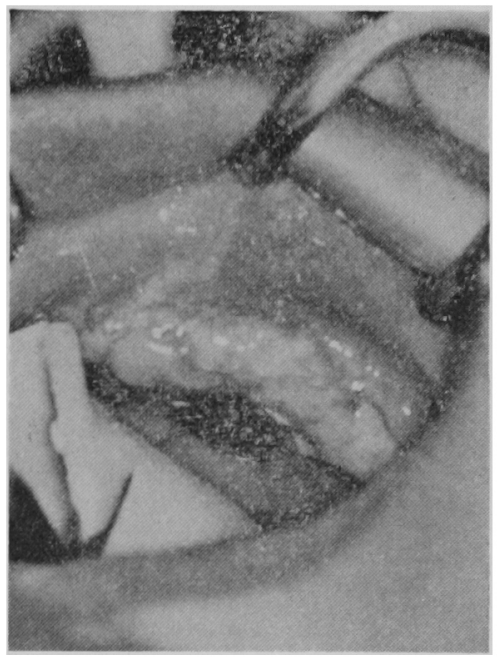

写直 23 人工皮度除去時の所見

(写真21).

flabby tissue に対する外科的手技には，全切除，電気 凝固法による除去，余分な組織をとったあとの弁による 被覆法などがあるが，本症例では余分な組織の切除が困 難で，このため全切除を行った，flabby tissue 切除後の 創面はほほ骨膜を残すのみとなりここ上に凍結乾燥豚 皮を敷きさらに人工皮虐を当てがい周国組織に释合固定

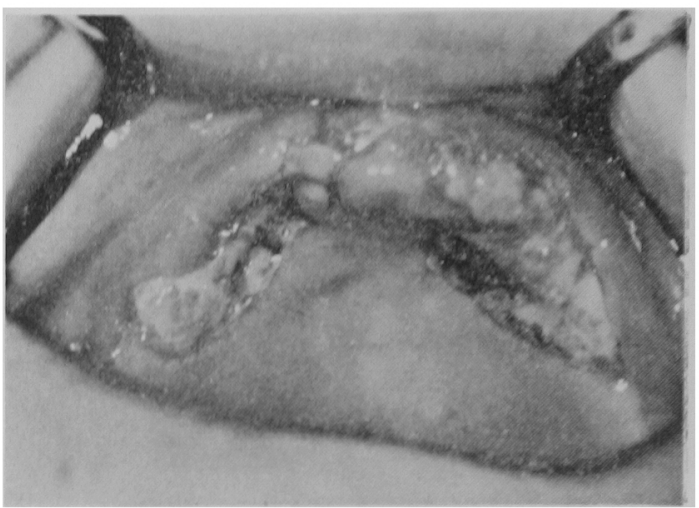

军真 24 人工皮庙除去嵝 6 日目の所見

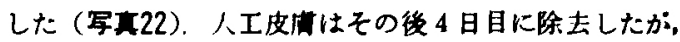

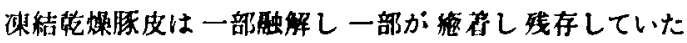

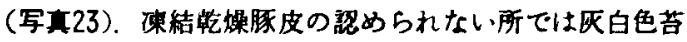
状物様を呈していた。 人工皮店除去後 6 日目の所見て

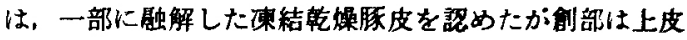
の新生によって樎小し周囲粘膜に移行しつつあった（写 士24).

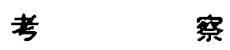

口腔外科領域の手術では手術創が口腔内に路出するこ とも多く、このような場合には，殺菌剩あるいは抗生物 質を添加したガーゼなどを簬出創に当て上皮の新生を待 つ法がとられてきた。しかし，ガーゼは㓣面と比較的 強く付着した形をとり、このガーゼ交换時に毫引的な力 を加えざるを得ないことも多い．この祭の患者の苦痛は 大きく、また創に対しては新生しかけた肉芽組織を别離 し出血を招くなといくつかの好ましくない状態が随伴す る.これらの状態を避けるため最近ではいくつかの生物 材料が応用され ${ }^{127}$ 手術創を保蒦する虔法が行われるよ らになった。

われわれの行っている手術創㞠法は， raw surface に 凍結乾燥豚皮を敷き，この上に人工皮庐を当て創周囲組

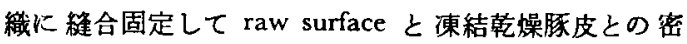
着をはかるすのである。

われわれの使用した涷結乾燥原皮は，国産の製品で biological dressing として熱傷, 皮唐制削創, 外傷性皮 唐欠損創などに適用され，xenograft の効果すなわち，局 所鎮痛奻果, 表皮再生促進効果, 肉芽形成効果, 細菌感 染抑制効果, 炎症反応抑制効果, biological debridement の効果, さらには治瘾後の洀痕を最小限にする効果のあ ることが報告されているものである゙．

口腔外科項域に扣ける倲結乾燥豚皮の応用は后骨除去 創, 義齿線䧽症切除創, 雪肉部減張切開による骨露出 創, エプーリス切除創 ${ }^{6\rangle}$, また, 崡槽堤形成手術, 腫瘍 


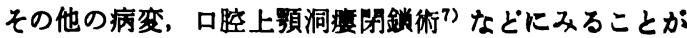

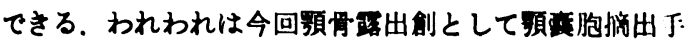
行、口盖弁を使用した口腔上䫑洞瘄閉銧手術への応用例 をまた軟組樴露出㓣として煩小带切除手術 flabby tissue 切除手術への応用例について報告したか，それらの症例 は代表的なるのにすぎず取近では手術に伴い発現した raw surface Kは, routine に註結落嬠豚皮を使用して いる．それらの経験を加えてわれわれの使用している嫁 結競燥豚皮の奻果について局所鉸痛奻果，表皮再成促進 奻果，肉芽形成奻果，細菌感染抑制奻果をとりあげ，以 下に恰討を加えてみる。

まず，局所鎮痛効果については，次結乾嬠豚皮で皮庙

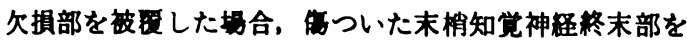
自然に近い環境に置くことにより鎮痛効果をるたらすと 説明されているが9)，これは，口腔外科手術創に対して るいえることであり，食物摄取をはじめとした直接的刺 敬から保荄されていることは大きな局所鎮痛奻果をむた らしている，ガーゼ交換を行わなくてもすむことも大き な鎮痛効果の役目を果しており最すすぐれた効果と思わ れる。

表皮再生促進効果については deep dermal burn の よ5に焼拁を形成する局所にはその奻力はなく， superficial dermal burn のよらな創面では良く局所に密着 し，表皮再生を速やかにするとされているが'10)，われわ れの場合，骨露出創では約 1 週後に，また，軟組織露出 創では約 4 日後に人工皮庙を除去し，このためその後凍 結鿒燥豚皮は口腔内にさらされることになり，食物摄取 などの刺で脱落するか，あるいは，脱落しない場合は 融解㑯向をみせ，このため表皮再生促進効果は確認でき ていない.

肉芽形成効果では，骨露出創での人工皮店除去時すな わち術後約 1 週目において良好な肉芽の形成がみられ， 軟組織露出創での人工皮庙除去時すなわち術後約 4 日目 においてる良好な肉芽の形成を認めた。 口腔外科手術創 においてる十分認められる効果と思われる。

細菌感染抑制効果については, 倲結乾燥豚皮自体の殺 菌能力によるものではなく，創面との密着に起因するる のであるとされているが ${ }^{10}$ 感染のおそれのある一定期間 を人工皮庙で压迫しておくわれわれの療法では，創傷部 の被覆保護による感染防止効果もあるものと思われる。

今回使用した凍結乾燥㟲皮の副作用としては，発熱， 皮庙反応などが 報告されているがいずれる重症熱傷患 者，皮庙剝削創などの䟢に発現したるのであり，現在ま でわれわれのところでは副作用の発現をみていない，免 度原性の問題に関してもきわめて副作用の少ないるのと されている10).

以上述べたよらな効果が十分発揮されるために必要な 条件は，創面と凍結乾燥豚皮との密着である，その方法 として, 高橋ら ${ }^{6)}$ は口蓋板, 義菡床の利用, モデリンク
コンパウンドによる压接, tie over 法、リパールカカー ゼの王迫法などをあげ, 杉崳ら7) は, tie over 法, plate による固定をあげている，われわれは人、波湍による圧

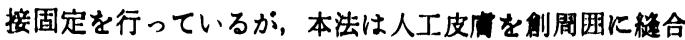
するだけの简便な方法である。

人工皮闭としては，八木ら(1)か明発した P・V・F sponge を使用したがここれは polyvinyl formal sponge といい，その生体への応用は1949年 Grindlay が胸腔内 充虽物として使用したのが初めてである。 わが国でも 1955年長石らが助膜外充埙物学として利用している。 一 般には熱伤㓣のほか，自家植皮の際の患皮部その他の 皮店欠損部などに䔔用され，生体への反応としては， Harrison, 渥美, 平川らにより異物としての反応がわ めて少ないと報告されている11)。この $P \cdot V \cdot F$ sponge の特性の 1 つに外部よりの細菌の侵入を防止し，かつ細 菌の発育阻止作用を有することがある。この原理につい て八木 ${ }^{111}$ は，製造過程において微量のホルマリンが混入 され、これが大きな因子として作用しているよらであ り, 動物実験ではこの程度のホルマリンでは異物反応す 含めて生体に与える影锌は問題にならないことが立証さ れていると述へている。

本法によって従来ミクリッッ・タンポン法などで処置 されてきた額骨における宾胞また腫瘍摘出による骨露出 創むガーセの交換を行らことなく，一定期間放置してお くことが可能となった．露出骨表面に肉芽組織が形成さ れ口腔内へさらされてす疼痛がなく，一方，感染の危険 あなくなる術後 1 週目頃には，人工皮庙を除去するよ5 にしているか，その後創表面に密着している凍結乾燥原 皮は無理に除去せず自然の脱落にまかせている．軟組織 露出創では，肉芽組織の形成す早く，術後 4 日目頃には 人工皮庙を除去するようにしているが，この早い時期で の人工皮庙の除去は，人工皮庙が骨露出創の場合に比へ 脱落しやすいことにもよっている，すなわち，骨露出創 のように陥凹の強い部に人工皮庙を固定するのと異な り，浅い軟組織露出侴では，人工皮席が口腔内に出る籍 囲が大きく，食物摂取その他の刺制で，周囲へ固定して ある挥合系が弛楥し，自然脱落する機会も多くなるため である。この軟組織露出創に対する固定には，今後さら に工夫をこらしていきたいと考えている.

いずれの場合も術後人工皮庙部は抗生物質溶液で洗涤 し感染の防止につとめたか，現在までかなり大きな骨貯 への使用も含め, 感染した症例はない.

結語

われわれは，口腔外科領域の手術に伴5 raw surface に対して，まず，倲結乾燥豚皮を敷きこの上に人工皮他 を当て創周囲組織に繾合固定して, raw surface と凍結 乾燥豚皮との密着をはかる療法を行っている．今回は， 


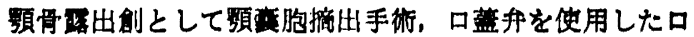

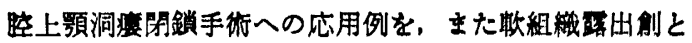
して 煩小带切除手術, flabby tissue 切除手術への応用 例について報告した。

本法によって骨露出刢，および，敢組織露出制とすに ガーゼの交換などを行らことなく一定期間放显しておく ことが可能となった。この結果，䚀者の苦痛す性減さ れ，通院回数す少なくてすむなと简便で有奻な手很創暴 法と考えている。

\section{引用文 献}

1）金田敬郎，他：柔㰩フィフリン膜の口腔手微へ の応用。日口外誌 19: 3571973.

2）畏谷川 明，他：額骨手䘗に対子るフィフリン

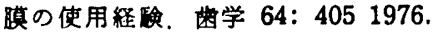

3）久野吉雄，他：雚胞摘出部への生物材の応用。 柴学 66: 1171978.

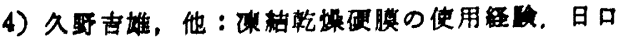
外誌 23: 602 1977.

5) Martis, C., et al.: Free transplantation of lyophilized dura for vestibuloplasty: a clinical and histological study. J Oral Surg 37: 646 1979.

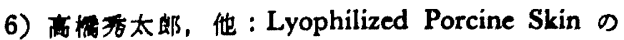

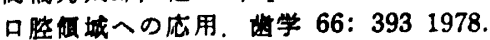

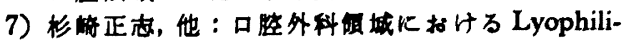

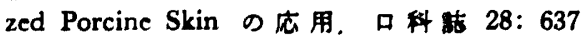
1979.

8) 4井 非, 他 : Lyophilized Porcine Skin(ASK-

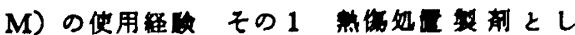
て. 2: 381975.

9) Elliott R.A.: Use of commercial porcine skin for wound dressing. Plast Reconstr Surg 52: 4101973.

10) 今井 進, 他: Porcine Skin の医床的奻果. 外 8: 681977 .

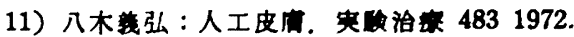

